Academic Platform Journal of Engineering and Science

journal homepage: $\underline{\text { http://apjes.com/ }}$

\title{
The influence of particle size on efficiency of quartz flotation
}

\author{
${ }^{* 1}$ Hüsnügül Yılmaz Atay, ${ }^{2}$ Mustafa Çırak \\ ${ }^{1}$ İzmir Katip Çelebi University, Department of Material Science and Engineering, 35620 Çiğli İzmir Turkey, \\ hgulyilmaz@gmail.com, \\ ${ }^{2}$ Muğla Sitki Kocman University, Department of Mining Engineering, 48000 Kötekli Muğla Turkey, mustafacirak@mu.edu.tr, \\ Research Paper \\ Arrival Date: 16.03 .2019 \\ Accepted Date: 02.03.2020
}

\begin{abstract}
Flotation is the separation of the particles of the ore according to their surface properties for floating on a given liquid to concentrate the desired phases. In this study, different size of minerals were used to achieve better flotation performance of mineral. It is devoted to investigate the influence of particle size on the separation efficiency. Prior to the beneficiation process, surface treatments were applied for obtaining agitated mineral surfaces. Flotation process provided the separation phenomena between the quartz mineral and associated impurities. In this study conventional flotation was used. X-ray diffraction (XRD), Scanning Electron Microscopy (SEM) and Energy Dispersive Spectroscopy (EDS) were used to perform the phase analysis, surface morphology and approximate composition of the quartz ore. The higher amount of flotation product was achieved with finer mineral. This is explained by the increase in surface area.
\end{abstract}

Keywords: Quartz, Flotation, Particle size, $\mathrm{PbSO}_{3}, \mathrm{Na}-\mathrm{Oleate}$.

\section{Kuvars flotasyonu veriminde tane boyutu etkisinin incelenmesi}

Flotasyon, istenen fazları konsantre etmek için belirli bir sıvı üzerinde yüzey özelliklerine göre cevher parçacıklarının ayrılmasıdır. $\mathrm{Bu}$ çalışmada, mineralin daha iyi yüzdürme performansını elde etmek için farklı boyutlarda mineraller kullanılmıştır. Partikül büyüklüğünün ayırma verimi üzerindeki etkisinin araştırılması amaçlanmaktadır. Zenginleştirme işleminden önce, mineral yüzeylerinin aktive edilmesi için yüzey işlemleri uygulanmıştır. Flotasyon işlemi, kuvars minerali ve ilgili safsızlıklar arasındaki ayrım işlemini sağlamıştır. Bu çalışmada geleneksel flotasyon kullanılmıştır. X-1şını kırınımı (XRD), Taramalı Elektron Mikroskobu (SEM) ve Enerji Dağılım Spektroskopisi (EDS), faz analizi, yüzey morfolojisi ve kuvars cevherinin yaklaşık bileşimini belirlemek için kullanılmıştır. Daha yüksek miktarda flotasyon ürünü daha ince minerallerle elde edilmiştir. Bu ise, yüzey alanındaki artışla açıklanmaktadır.

Anahtar Kelimeler: Kuvars, Flotasyon, Tane boyutu, $\mathrm{PbSO}_{3}, \mathrm{Na}-\mathrm{Oleate}$.

\section{INTRODUCTION}

Quartz is one of the most abundant and common minerals in the World. It has chemical and physical stability at Earth's surface conditions. Due to its solubility most natural waters contain dissolved silica that can precipitate as quartz associated with many different minerals $[1,2]$. Regarding the usage area, it goes without saying that quartz is the source of many items we see around from windowpanes and crystal goblets to eyeglasses and stained glass windows [1]. As well as used as a traditional material, quartz is used in the markets of glass, ceramics, and fillers to high-end, high-tech uses such as electronics, optics, semiconductors, lighting, infrared, specialty glass, fiber optics, and the computer and communications industries. Fused silica, or fused quartz, is the common term that applies to silica in most of these hightech markets. In those high-tech applications, high purity quartz are required. Especially during World Wars I and II, such purity was considered a strategic supply for early communications, such as radio [3]. Actually, for production of all advanced materials, very pure raw materials are desired. Those are said to be the materials which have engineered properties created through the development of specialized process and synthesis technology, such as composites, advanced electronic, ceramic, magnetic, optical materials, Nano-materials and biomaterials, etc. In connection with this, high quality quartz containing minor amount impurities are preferred in the new age. 
Quartz purity/quality largely depends on the beneficiation performance as structural impurities, such as feldspar, kaolinite etc., are difficult to remove [2]. By heating the quartz, fluid inclusions can be removed however some stable elements can be leaved in solution. In the heating process fluid inclusions decrepitate and other contaminants included in the gas phase [4]. Nevertheless, it is not clear to which extent the contaminants present in the liquid inclusions leave in form of gaseous compounds. Solid inclusions are generally formed at the grain boundaries, and it is possible to remove them by using mineral processing techniques. Within this context, for the physical separation of the mineral particles, comminution and separation techniques can be applied. The gangue mineral size will determine the required size reduction to be provided by these techniques $[5,6]$.

In this study, it was attempted to increase the beneficiation performance of quartz by using different size of minerals because particle size effect is one of the important factors in the flotation. Flotation characteristics and particle size distribution of micro-fine low rank coal were studied by $\mathrm{Qu}$ et al. [7]. They observed that the dominant size fraction of the low rank raw coal was $-0.045 \mathrm{~mm}$ size fraction with a yield of $91.65 \%$ and ash content of $46.25 \%$. The concentrate contained $83.38 \%$ of $-0.045 \mathrm{~mm}$ size fraction $(38.04 \%$ of total particles in feed) with ash content of $24.98 \%$. Additionally, tailing was formed of $-0.045 \mathrm{~mm}$ size fraction $(93.63 \%)$ with a higher ash content of $60.82 \%$. Besides, it is found in a coal flotation study that the best flotation selectivity was observed from the middle size fraction, $0.250+0.075 \mathrm{~mm}$, but the selectivity of $-0.500+0.250$ and $0.075 \mathrm{~mm}$ particles was decreased [8]. In another work it is investigated that the coal slime size fraction of $-0.125+0.074$ $\mathrm{mm}$ possessed the highest flotation rate [6]. Xia et al. [10] depicted that the range from $11 \mu \mathrm{m}$ to $74 \mu \mathrm{m}$ was found to be the best particle size for the flotation of heavily oxidized coal. Moreover, there are investigations regarding the particle size distribution effects on the strength values of German brown coal and the coalwater slurries rheology $[11,12]$.

Prior to beneficiation process, chemical surface treatments were applied to different particle size minerals. It was devoted for improving the flotation performance as an important phenomenon for mineral enrichment. The influence of particle size on the separation efficiency was investigated. Phase and mineralogical analysis were observed by XRD and XRF. SEM-EDS analysis were applied for investigating structural and morphological properties of the material. Flotation technique was used for increasing the grade of useful components in the material.

\section{EXPERIMENTAL}

The quartz material was received from Muğla region in Turkey. Samples were taken for characterization tests and beneficiation studies. Crushing was performed with a jaw crusher, the discharge opening was $2 \mathrm{~cm}$. Then crushed material was ground in a ball mill, alumina balls with various diameter were used as grinding media. Grinding time was 10 min. Any possible contaminations were prevented during these steps. After crushing and grinding, the low grade material was sieved to be separated into different particle size fractions. Four narrow sieved fractions of the material were used; sieved fractions $(\mu \mathrm{m}):-400+180(400 \geq x>180)$, $180+75 \quad(180 \geq x>75), \quad-75+38(75 \geq x>38), \quad-38(38 \geq x)$. The openings of the sieves were $38,75,180$ and $400 \mu \mathrm{m}$. With $100 \mathrm{~g}$ samples, sieving was applied. Because $50 \mathrm{~g}$ material is needed in the flotation process, sieving was repeated until getting $50 \mathrm{~g}$ each of fractions. Any possible slime \& slime coating problem is minimized by using the dilution. The material was analyzed with X-ray Fluorescence Spectrometry by Mikroman A.Ş. The mineral analyses is as following; $84.8 \% \mathrm{SiO}_{2}, 12.5 \%$ feldspar and other alkalies. Xray diffraction analyses were conducted using a Rigaku SmartLab XRD (X-Ray Diffractometer) device. SEM micrographs were taken with JEOL JSM-7600F SEM Scanning Electron Microscope. Elemental analysis was provided by Energy Dispersive X-ray Spectroscopy (EDS).

Regarding the beneficiation technique, flotation method was used. It is a physico-chemical separation process that uses the difference in surface properties of the valuable minerals and the unwanted gangue minerals $[13,14]$. One liter capacity Denver type flotation machine was used for the purpose. Na-Oleat was used as the collector and $\mathrm{Pb}\left(\mathrm{SO}_{3}\right)$ as activator for the flotation of quartz as described in Ref [15]. It was stated that different zeta potential values were obtained on the quartz and feldspar surfaces in different $\mathrm{Na}$ Oleate concentrations. Although there is no direct interaction between the surface of quartz and oleate due to the electrostatic repulsion stemmed from their negative charges, oleate can adsorb on the particle through a cation bridge mechanism. For instance, the lead ion hydrolyzes into $\mathrm{PbOH}+$ at certain $\mathrm{pH}$ values and these positively charged hydrolyzed ions strongly adhere themselves to the negatively charged particle surface due to the electrostatic attraction. Following the adsorption of these kind of hydrolyzed species, the quartz surface become activated for the attachment of the collector. Namely, hydrolyzed cation serves as a bridge between two negatively charged matter and the resultant (Quartz $+\mathrm{PbOH}+$ Oleate) form a hydrophobic surface that can be collected in the froth phase [16]. Due to this difference it was claimed that it is possible to separate feldspar and quartz. Though, $\mathrm{Pb}$ ions were chosen as an activator, because under the conditions applied, $\mathrm{Pb}$ undergoes hydrolysis to form $\mathrm{PbOH}+$. The flotation tests were performed after the samples are conditioned with the reagents for a specified time at a fixed pulp density. $1 \mathrm{~min}$ allowed before collecting the froth in the flotation. The concentrate and tailing were collected separately, dried, weighed and analyzed for different constituents to assess the product quality. Table 1 depicts the flotation experiment conditions. 
Table 1. Optimum conditioning parameters for flotation.

\begin{tabular}{cc}
\hline $\mathrm{pH}$ & 7 \\
\hline Powder size distribution & $-38,-75+38,-180+75,-$ \\
Collector & $400+180$ \\
Activator & $\mathrm{Na}-\mathrm{Oleat}, 2000 \mathrm{~g} / \mathrm{t}$ \\
Frother & $\mathrm{PbSO}_{3}, 300 \mathrm{~g} / \mathrm{t}$ \\
$\mathrm{MIBC}^{2}, 30 \mathrm{~g} / \mathrm{t}$ \\
$\mathrm{PbSO}_{3}$ conditioning time & $1 \mathrm{~min}$ \\
$\mathrm{Na}-\mathrm{Oleat}_{\text {conditioning time }}$ & $3 \mathrm{~min}$ \\
Conditioning time with & $1 \mathrm{~min}$ \\
frother & $1100 \mathrm{rpm}$ \\
Rotor speed &
\end{tabular}

\section{RESULTS AND DISCUSSIONS}

XRD analysis of the flotation feed is shown in Figure 1. The main phase is quartz with the impurities of feldspar and other alkalies. SEM micrographs are depicted in Figure 2. Whether there was any difference in the images according to the size change was determined. However, these images showed that the morphology of the materials significantly similar. They have irregular shapes with some elongated particles. EDS analysis supports X-ray diffraction results that the material consists of $\mathrm{O}, \mathrm{Na}, \mathrm{Al}, \mathrm{Si}$ elements (Figure 1).

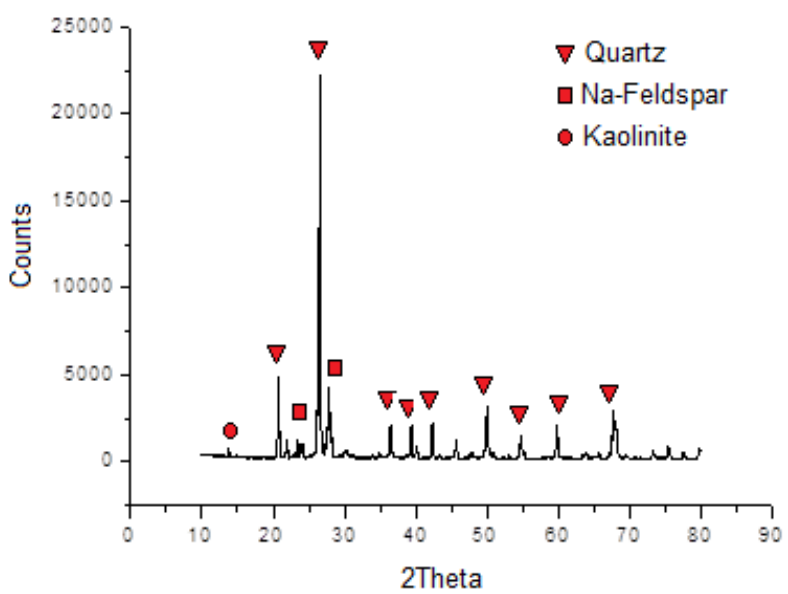

Figure 1. XRD analysis of the raw material, Flotation feed.

In the flotation experiment a very successful performance was obtained, as shown in Table 4. Chemical analysis of the concentrate as follows; coarse size $(-400+180) \mathrm{m}) 94.7 \%$ $\mathrm{SiO}_{2}$ and fine size $(-38 \mathrm{~mm}) 96.1 \% \mathrm{SiO}_{2}$. It can be seen that reducing the size of the particles reduces waste. This means that quartz improves flotation performance. As noted, this may be due to the increased surface area and the release of valuable material. On the other hand, the separation of feldspar and quartz was successful in this flotation experiment by using $\mathrm{Pb}$ ions as an activator. This can be explained by the differences in zeta potential on the surface of feldspar and quartz caused by the effect of $\mathrm{Pb}$ ions. Gulsoy et al. [15] investigated the possibility of using metal ions ( $\mathrm{Al}$, $\mathrm{Ba}, \mathrm{Mg}, \mathrm{Pb}$ and $\mathrm{Sn}$ ) in selective oleate flotation of feldspar from quartz.
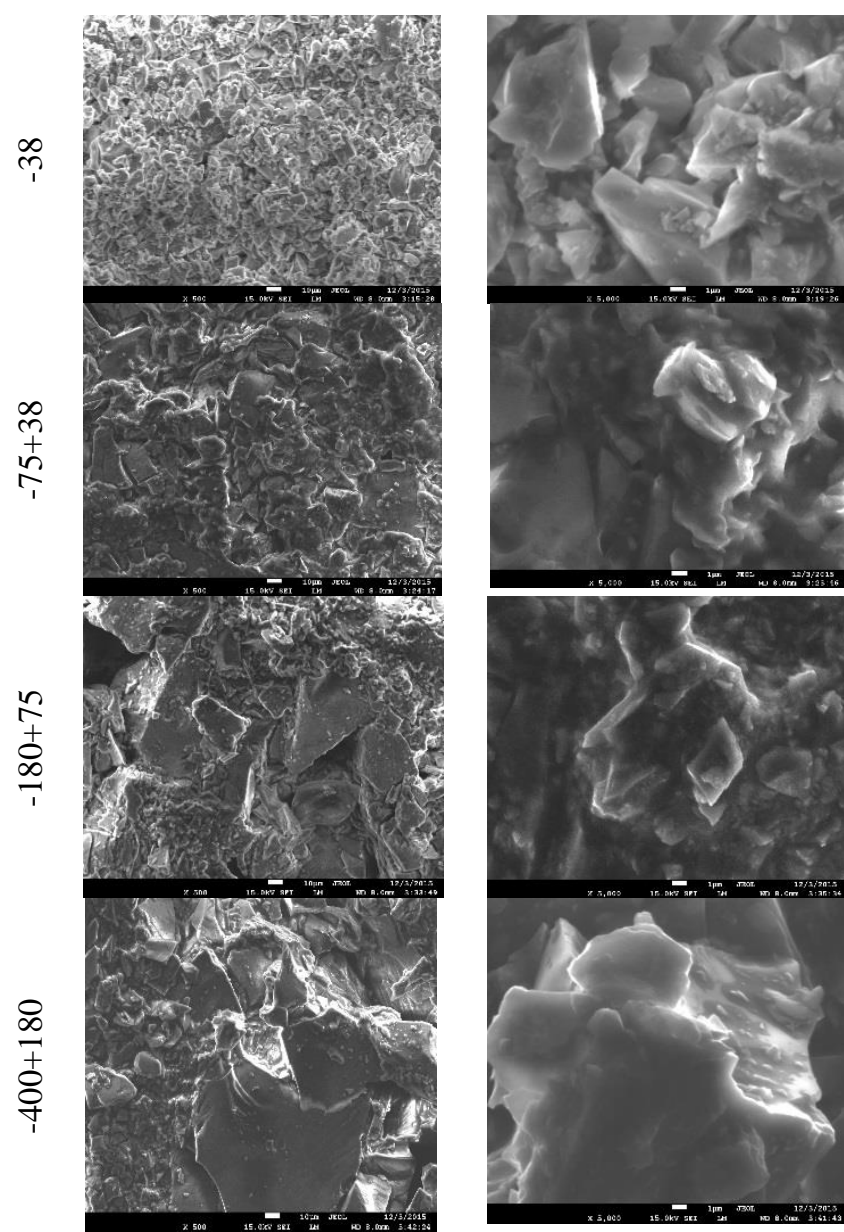

Figure 2. SEM micrographs of different size of mineral,

Flotation feed.
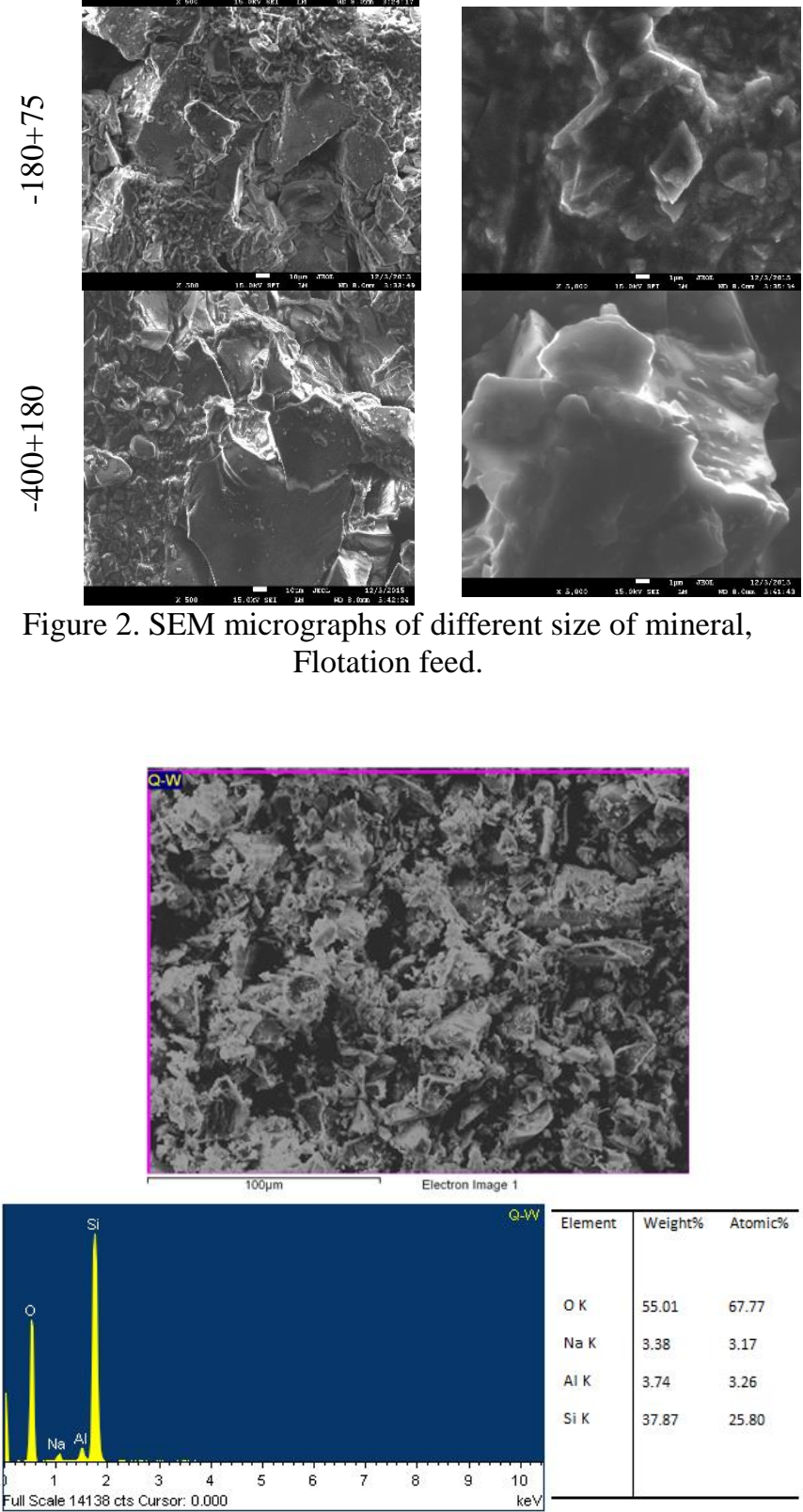

Figure 3. EDS analysis of the mineral, Flotation feed. 
They observed that the surface charges of quartz and feldspar were almost identical in the presence of $\mathrm{Al}, \mathrm{Ba}, \mathrm{Mg}$ and $\mathrm{Sn}$ ions. However, when oleate was used after conditioning with lead ions, a slight difference was observed in the surface charges of both minerals [6].

Table 4. Flotation results according to the particle size of quartz.

\begin{tabular}{cccc}
\hline $\begin{array}{c}\text { Particle } \\
\text { size } \\
(\mu \mathrm{m})\end{array}$ & $\begin{array}{c}\text { Concentrate } \\
(\mathrm{g})\end{array}$ & $\begin{array}{c}\text { Tailing } \\
(\mathrm{g})\end{array}$ & $\begin{array}{c}\text { Flotation } \\
\text { Recovery } \\
\text { Oxides } \\
(\%)\end{array}$ \\
\hline$-400+180$ & 31.1 & 18.9 & 62.2 \\
$-180+75$ & 34.0 & 16.0 & 68.0 \\
$-75+38$ & 35.1 & 14.9 & 70.2 \\
-38 & 36.5 & 13.5 & 73.0 \\
\hline
\end{tabular}

XRD analysis was performed each fraction of the flotation concentrate and the tailing. The results were demonstrated in Figure 4.

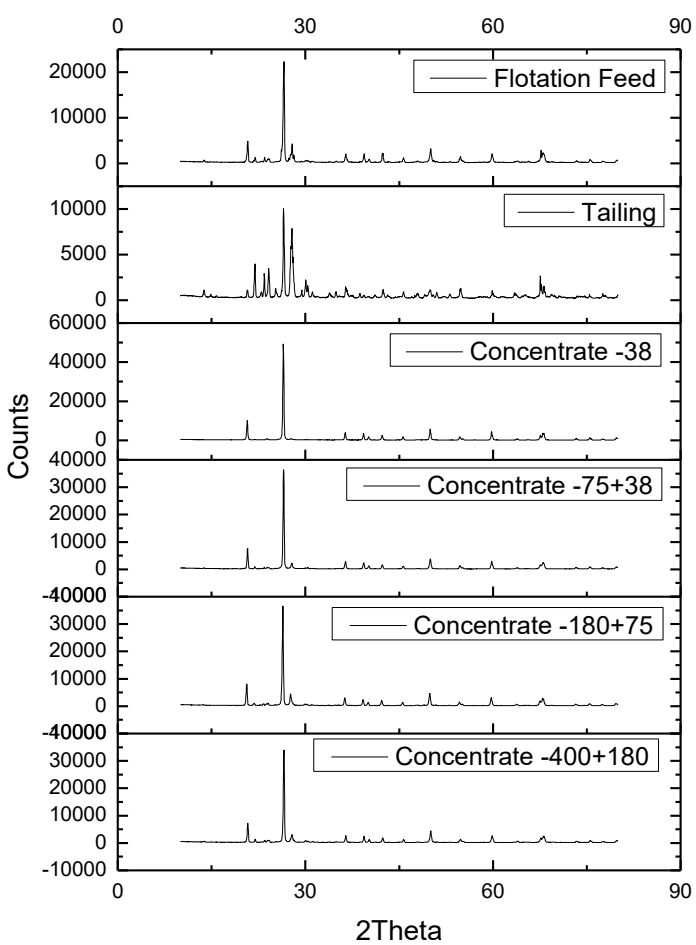

Figure 4. XRD analysis of the flotation feed, tailing and concentrates

XRF analysis was used for the investigation of $\mathrm{SiO}_{2}$ existence to observe the quartz quantity in the flotation product. The results were shown Figure 5. It can be seen that $\mathrm{SiO}_{2}$ content of the coarser $(-400+180)$ fraction was $94.2 \%$, but it increased to $96.1 \%$ by decreasing material size. This result supports XRD analysis.
Although a de-sliming step is required in most plant practices, the increase in $\mathrm{SiO} 2$ in the concentration shown in Figure 5 shows us that this is not the slime, but quartz in the concentrate. However, a de-slimming step would still be good for improving the quality of the product.

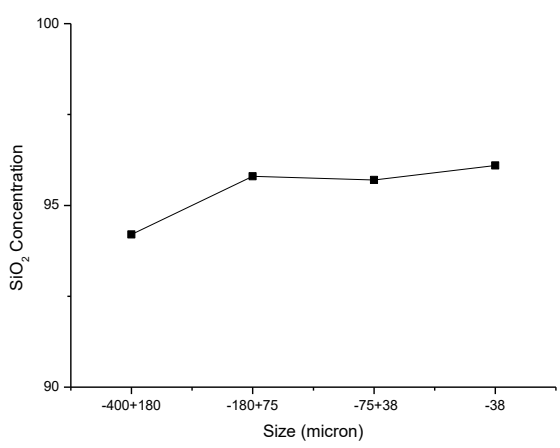

Figure 5. XRF analysis of the flotation product, Concentrates.

Those analyses proved the improvement in the flotation performance by reduction of the feed particle size. The same result is observed a greater number of interparticle contacts and more interlocking. Thus this leads to a lower coefficient of friction, and/or higher contact angle, resulting in lower capillary forces $[17,18]$. On the other hand, Crawford et al. obtained similar results with different reagents that critical contact angle for floatability of mineral particles varies with the particle size fraction $[19,20]$. It is depicted that in the solids separation -flotation- technique, success depends on the utilizing of a variety of particle size, chemical reagents and wetting behavior of solid surfaces and particle dispersion. All of those; particle size, shape, wetting property and the response behavior to the surface treatments need to be considered during the evaluating the flotation results.

The experimental work and the characterization proved that the decrease in the particle size of the feed prior to the flotation resulted in the generation of the fresh particle surface and the greater surface area. Once the abovementioned outcomes were achieved by decreasing the feed down to $-38 \mu \mathrm{m}$, the flotation performance significantly enhanced. XRD and XRF outputs showed that the gangue particles were potently separated from the quartz particles with the help of Na-Oleate. When the dissolution of $\mathrm{PbSO}_{3}$ took place during the conditioning, $\mathrm{Pb}$-ions were hydrolyzed and formed varying aquatic $\mathrm{Pb}$-species. In the studied $\mathrm{pH}$, it is determined that the dominating species was $\mathrm{PbOH}^{+}$in the flotation cell. This specific product was a vital component since it is responsible for the activation of the system. The mechanism behind the activation process can be explained with the formation of a metal $(\mathrm{Pb})$ hydrous - oleate complex. In conclusion, the size reduction improved the effective surface area and the liberation of the minerals in the natural ore sample. Then, the $\mathrm{Pb}$-oleate complexes firmly attached themselves on these freshly generated quartz surfaces, selectively. The combination of these mechanical and 
chemical activations significantly improved the quality of the final product

\section{CONCLUSIONS}

In the scope of this work, the effect of the feed size on the flotation performance of quartz particles was investigated and the results were supported with the detailed characterization studies. The original quartz ore was classified into four different categories based on the particle sizes, namely $-400+180 \mu \mathrm{m},-180+75 \mu \mathrm{m},-75+38 \mu \mathrm{m},-38 \mu \mathrm{m}$. Each of these fraction was subjected to the froth flotation by using Na-Oleate as a collector. The products of each work were characterized with the implementation of XRD, XRF, SEM, EDS methods.

The characterization part of the study showed that the grade of $\mathrm{SiO}_{2}$ can be increased from $84 \%$ up to $96.1 \%$ just by decreasing the feed size down to $-38 \mu \mathrm{m}$. The processing of the coarser feed fractions $(-400+180 \mu \mathrm{m},-180+75 \mu \mathrm{m}$,$75+38 \mu \mathrm{m}$ ) failed to succeed this grade level for the quartz enrichment. The XRD-based mineralogical analysis of each flotation product proved that gangue particles were successfully reported in the tailing whereas froth contained higher-quality quartz product. Among all XRD spectrums, the highest intensity diffraction peak was obtained for the product of the flotation carried out for $-38 \mu \mathrm{m}$ feed. This peak was an indicator for the quantitative phase analysis and it confirmed that the greatest mineralogical abundance of quartz particle was obtained after the flotation of the feed ground at $-38 \mu \mathrm{m}$.

In SEM analysis, it is clearly seen that grain size is reduced. This allowed the surface area to be increased and thus the contact point to be increased. Thus this provided newly formed fresh surfaces for the effective adsorption of the collector following the particle size reduction. Furthermore, flotation significantly improved at $-38 \mu \mathrm{m}$. It was revealed that these variations in the morphology of the sample during the comminution contributed to the physicochemical recovery of the quartz particles. In conclusion, the low-grade ore was beneficiated up to the refractory grade with the implementation of the size reduction and the surface activation of the quartz particles via $\mathrm{Pb}$ ions.

\section{REFERENCES}

1. Quartz Silica Group of Silicate Minerals. University of Minnesota, Retrieved 5th December 2018. https://www.esci.umn.edu/courses/1001/minerals/quartz.sht $\mathrm{ml}$

2. E.D. Martello, Impurity distribution and reduction behaviour of quartz in the production of high purity silicon. Thesis for the degree of Philosophiae Doctor. Norwegian University of Science and Technology, Norwey, 2012.

3. J.E. Kogel, N. Trivedi, J.M. Barker, S.T. Krukowski, Industrial Minerals \& Rocks - Commodities, Markets and Uses, Society for Mining, Metallurgy and Exploration Inc.
Englewood, U.K, 2006.

4. M. Gemeinert, M. Gaber, I. Hager, M. Willhfahrt, D. Bortschuloun. On correlation of Gas-Liquid inclusion's Properties and Melting Behaviour of Different Genetic Quartzes for Production of Transparent fused Silica. Neues Jahrbuch Miner. Abh. 165, 19-27, 1992.

5. U. Andres, J, Jirestig, Timoshkin Liberation of minerals by highvoltage electrical pulses. Powder Tehcnol 104, 3749,1999 .

6. F. Göktepe, H. Ipek, M. Göktepe. Beneficiation of quartz waste by flotation and by ultrasonic treatment. Physicochem. Probl. Miner. Process. 47, 41-50, 2011.

7. J. Qu, X. Tao, L. Tang, N. Xu, H. He. Flotation characteristics and particle size distribution of micro-fine low rank coal. Procedia Engineering 102, 159-166, 2015.

8. Y.F. Li, W.D. Zhao, X.H. Gui, X.B. Zhang, Flotation kinetics and separation selectivity of coal size fractions, Physicochem. Probl. Miner.Process. 49, 387-395, 2013.

9. X.H. Gui, J.T. Liu, X.X. Tao, Y.T. Wang, Y.J. Cao, Studies on flotation rate of a hard to float fine coal, J. China Coal Soc. 36, 895-1900, 2011. (in Chinese).

10. W.C. Xia, J.G. Yang, B. Zhu, The improvement of grindability and floatability of oxidized coal by microwave pre-treatment, Energy Source Part A, 36, 23-30, 2014.

11. S. Zhong, F. Baitalow, P. Nikrityuk, H. Gutte, B. Meyer, The effect of particle size on the strength parameters of German brown coal and its chars, Fuel, 125, 200-205, 2014. 12. F. Boylu, H. Dincer, G. Ateşok, Effect of coal particle size distribution, volume fraction and rank on the rheology of coal-water slurries, Fuel Process. Technol. 85, 241-250, 2004.

13. R. H. Urbina, Recent developments and advances in formulations and applications of chemical reagents used in froth flotation. Mineral Processing \& Extractive Metall. Rev, 24, 139 182, 2003.

14. R.D. Kulkarni and P. Somasundaran. Flotation chemistry of hematite/oleat system. Colloids and Surfaces. 1, 387-405, 1980.

15. Ö.Y. Gülsoy and F. Kılavuz, The Use of Na-Oleate with metal salts as a Collector in K-Feldspar Quartz Flotation. Madencilik, 22-34, 2002. (in Turkish).

16. S. M. Bulatovic. Handbook of flotation reagents: chemistry, theory and practice: Volume 1: flotation of sulfide ores. Elsevier, 2007.

17. H. Wotruba, H. Hoberg, FU. Schneider. XVIIth Int Miner ProcessCong IV. 83-95, 1991.

18. N. Vlachos, I.T.H. Chang. Graphical and statistical comparison of various size distribution measurement systems using metal powders of a range of sizes and shapes. Powder Metallurgy. 54, 497-506, 2011.

19. R. Crawford \& J. Ralston. The Influence of Particle Size and Contact Angle in Mineral Flotation. International Journal of Mineral Processing. 23. 1-24. 1998

20. S. Muganda, M. Zanin, S. Grano. Influence of particle size and contact angle on the flotation of chalcopyrite in a laboratory batch flotation cell. International Journal of Mineral Processing. 98. 150-162. 2011. 